\title{
Study of a Crustacea Decapoda Taxocoenosis of Posidonia oceanica Beds from the Southeast of Spain
}

\author{
J. E. García-Raso \\ Dept. Biología Animal (Zoología), Fac. Ciencias, Univ. Málaga, E-29071 Málaga, \\ Spain.
}

With 8 figures and 3 tables

Key words: Crustacea, Decapoda, Posidonia oceanica, taxocoenosis, Spain, Mediterranean Sea.

\begin{abstract}
During 1986 and 1987 a decapod crustaccan taxocoenosis of Posidonia oceanica beds from the southeast of Spain has been studied.

Data on abundance-dominance of the 50 species found and other information such as reproduction and the selective use of gastropod shells by the dominant hermit crabs are given.

Differences in richness and equitability between shallow $(3-4 \mathrm{~m})$ and deeper $(5-7 \mathrm{~m})$ samples are also shown.

The taxocoenosis presents a geometrical distribution in which only 9 species have a relative abundance higher than $1 \%$ and in which the strueture is basically controlled by the two dominant hermit crabs, Cestopagurus timidus and Calcinus tubularis, and hydrodynamic conditions.
\end{abstract}

\section{Problem}

Infralittoral Posidonia oceanica beds represent an important nursery and shelter for many animals and seaweeds, and has been called an "oasis of life" (Boudouresque \& Meinesz, 1982). It exhibits a complex biotic community (PÉrès \& PiCARd, 1964; Kikuchi \& Pérès, 1977), with a high richness, in which many animals spend all or part of their lives. More than 1000 different species have been mentioned in the literature (e.g., HarmeIIN, 1964; SAN MARTIN \& Vieitez, 1984, on Polychaeta; Bourcier \& Wilısie, 1986, on Sipunculida; Templado, 1984 a, on Mollusca; Boero, 1981 a, b, on Hydroidea; Benito, 1987 ; Pansini \& Pronzato, 1985, on Porifera; Harmelin, 1973, on Bryozoa; BellanSANTINi et al., 1986, on Amphipoda; LoPEZ-IBor et al., 1982, on Echinodermata; Bell \& Harmelin-Vivien, 1983, on fishes; and Mateu, 1970, on Foraminifera).

This community inhabits the two strata of Posidonia, the leaves (photophilous) and rhizomes (sciaphilous), in which two different epiphytic associations have been described (Molinier 1959-60; Ben, 1971; and Boudouresque, 1968: Posidonietum oceanicae or Myrionema orbiculare - Giraudia sphacelarioides 
and Peysonnelia squamaria or Udoteo-Peyssonnelietum, respectively). The animal community here has been subdivided into four or five subunits according to microhabitat structure and mode of life (KIKUCHI \& Pérès, 1977; Kı́uCHI, 1980). This high animal diversity results in a large number of inter- and intraspecific strategies, which are further governed by intrinsic and extrinsic factors such as light-dark periodicity, seasonal influences, hydrodynamic conditions, depth, and the influence of adjoining biotopes.

Also, Posidonia beds are very important in the infralittoral trophic chain, thus forming a key element of the latter (TRAER, 1980; NEDELEC et al., 1981; Verlaque, 1981; Wittmann et al., 1981; Chessa et al., 1983; Zupi \& Fresi, 1985; Beli \& Harmelin-Vivien, 1983).

This brief introduction aims at providing a general view of the importance and complexity of the studied seagrass. Although many published works exist, little is known about the quantitative structure of the faunal community and its temporal evolution. Also, the significance of the species, mainly the dominant ones, to community structure is unknown (as is also the case in other seagrasses such as Zostera marina, see Thayer et al., 1984).

Moreover, no specific papers on Decapoda exist; the best references are found in general studies (Pérès \& Picard, 1964; Ledoyer, 1966 and 1968, in the foliar stratum; Harmelin, 1964, in rhizomes; and Templado, 1984b, in the Spanish littoral).

\section{Material and Methods}

\section{Study area}

The study area is located in southeast Spain off the Genoveses beach in the Nature Park of Cabo de Gata, Almería.

The Posidonia bed is small, is located on a soft bottom with few rocks, and is in good condition. Its bathymetric range is between 1 and $10 \mathrm{~m}$.

In comparison with the Posidonia beds from Ischia, Gulf of Naples (whose range is from 1 to $30 \mathrm{~m}$ and in which four different zones have been defined; Scipione et al., 1983), the studied bathymetric area would correspond to the transition $(2-4 \mathrm{~m}$, charactcrized by a peak richness in groups such as Isopoda, LORENTI \& FreSI, 1983) and typical (6-12 m) zones of the animal community.

\section{Sampling}

In 1986 and 1987, bi-monthly samples were always collected at approximately 11:00a.m., using SCUBA equipment (except under bad weather conditions). The sampling depth during the first year was 3 to $4 \mathrm{~m}$, in the sccond year 5 to $7 \mathrm{~m}$.

The sample area was always greater than $900 \mathrm{~cm}^{2}(30 \times 30 \mathrm{~cm})$ and the rhizome height always about $20 \mathrm{~cm}$. The minimum area suggested by HARMELIN (1964) was somewhat larger, but his sieve mesh was wider $(1.8 \mathrm{~mm})$. DE METRIO et al. (1978) established a minimum area of $950 \mathrm{~cm}^{2}$ for the total benthos, but they did not include crustaceans in the study, employed a different method (involving "aspiration" on leaves), and used a $5 \mathrm{~mm}$ mesh (thus loosing some of the smaller specimens and missing many of those hidden in the rhizomes). Other authors used a smaller area $(20 \times 20 \mathrm{~cm})($ ERGEN et al., 1988).

The rhizome height in our samples allows the capture of members of the few species that have a vertical distribution, since these are rarely found deeper than $10 \mathrm{~cm}$ and most inhabit the first $4 \mathrm{~cm}$ (Willsie, 1983; Harmelin, 1964). 
The samples (rhizomes with their leaves) were pulled out and immediately placed (in situ) in plastic bags by two divers. Thus, only the most rapidly swimming species which hide among the leaves, do not utilize the rhizomes as a refuge, and have a small population density could escape. To verify this a different sampling method was used: a $30 \mathrm{~cm}$ net $(2 \mathrm{~mm}$ mesh) provided with a closing mechanism was dragged across the leaves in an adjoining $12 \mathrm{~m}^{2}$ area for $10-15 \mathrm{~min}$.

In the laboratory the leaves and rhizomes of each sample were separated and washed using a three sieve column (smallest mesh $0.5 \mathrm{~mm}$ ). This method retained even postlarvac or megalopes, which were not included in the study but provided information on recruitment times.

After separating the fauna, the leaves and rhizomes were dried at $105^{\circ} \mathrm{C}$ for $48 \mathrm{~h}$. These dry weights served as a quantifying basis for the faunistic data.

In the numerical analysis the absolute and relative abundances of all species from all samples were calculated. For purposes of comparison, the absolute abundances of the dominant species were referred to $1000 \mathrm{~g}$ dry weight of the sample.

Diversity, using the SHANNON-WEaver index, the equitability, and the dominance-diversity curves (García-Raso \& Fernandez, 1987; García-Raso, 1988) were also calculated. Finally, in order to detect the similarity between samples from quantitative data, an analysis of principal coordinates ( $Q$ mode) was carried out.

\section{Results}

Taking constant rhizome height into account enables clear presentation of the relation between rhizome and leaf weight (Fig. 1); this represents the variation tendency in the foliar area over the study period. This evolution is of great interest since it governs epiphyte biomass during the cycle. Ephiphyte biomass in turn represents an important "step" in the trophic network of the system.

The minimum is apparent at the beginning of winter and the maximum in summer. However, the maximum foliar area is less marked in the shallower samples than in the deepest ones; these were found in May and August, respectively. Moreover, the foliar area shows a clear drop in shallower waters in summer and autumn when winds do the greatest damage to the studied area (pers. observ.).

Fig. 1. Evolution of leaf dry weight $/ 1000 \mathrm{~g}$ rhizomes, at $3-4 \mathrm{~m}$ (1986) and $5-7 \mathrm{~m}$ (1987) in the studied area.

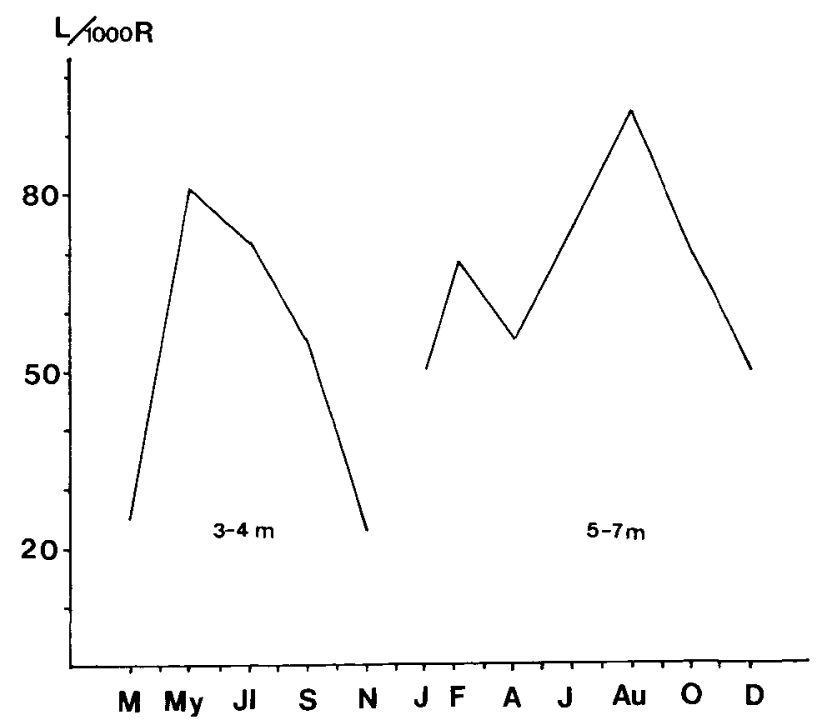



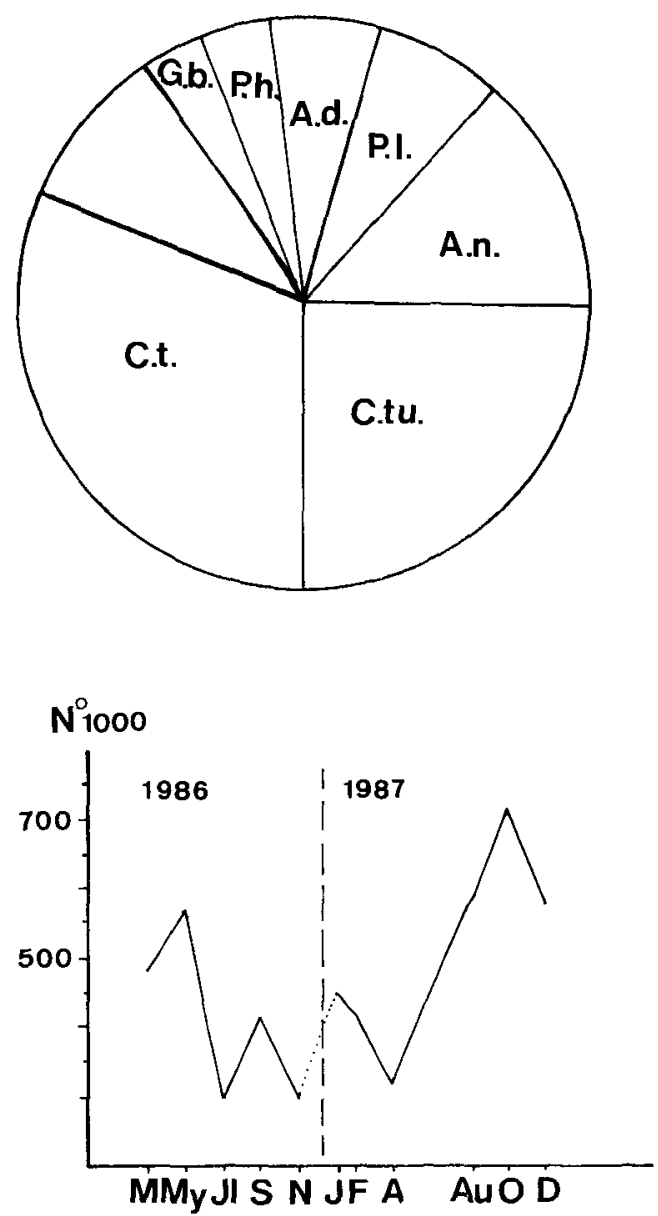

Fig. 2. Abundance of the seven most dominant specics.
Fig. 3. Evolution of the general abundance of dccapods during 1986 (at 3-4 m) and 1987 (at $5-7 \mathrm{~m}$ ), referred to $1000 \mathrm{~g}$ dry weight of sample (leaves and rhizomes).

\section{Faunistic results}

The monthly and annual faunistic information obtained and the relative and absolute abundance of the different species during the study period (1986-1987) is shown in Tables 1 and 2 .

\section{a. Composition, abundance, and dominance}

A total of 6585 specimens belonging to 50 species were captured.

In spite of the high richness, the decapod taxocoenosis is dominated by few species. Only 9 have a relative abundance higher than $1 \%$ and represent $95.4 \%$ of the total individual numbers (Table 3). These are: Cestopagurus timidus $(31.6 \%)$, Calcinus tubularis $(25.3 \%)$, Athanas nitescens $(13.6 \%)$, Pisidia longicornis $(7.4 \%)$, Alpheus dentipes $(6.0 \%)$, Pilumnus hirtellus $(4.1 \%)$, Galathea bolivari $(3.9 \%)$, Thoralus cranchii $(2.5 \%)$, and Pilumnus villosissimus $(1.0 \%)$. 
Table 1. Faunistic survey of 1986. Absolute and relative abundances are given for cach species and studied month. Asterisks denote the presence of ovigerous females. Total abundance is indicated in the right margin. At the bottom, volumes (rhizome and leaf dry weight) for each sample in grams, the absolute abundance total (No.), the amount referred to $1000 \mathrm{~g}$ of dry weight, richness $(S)$, the diversity index $\left(\mathrm{H}^{\prime}\right)$, and equitability $\left(\mathrm{J}^{\prime}\right)$ are given.

In the first month of study two samples were taken, one at $9 \mathrm{~m}$ and the normal one at $3-4 \mathrm{~m}$.

\begin{tabular}{|c|c|c|c|c|c|c|c|}
\hline $1986 \mathrm{day} / \mathrm{month}$ & $\begin{array}{c}9 \mathrm{~m} \\
26 / 3\end{array}$ & $26 / 3$ & $23 / 5$ & $\begin{array}{l}3-4 \mathrm{~m} \\
21 / 7\end{array}$ & $17 / 9$ & $13 / 11$ & Total $3-4 \mathrm{~m}$ \\
\hline 2 Processa macrophthalma & - & - & 10.2 & - & $3 \quad 0.6$ & - & $4 \quad 0.20$ \\
\hline 5 Hippolyte longirostris & - & - & $1 \quad 0.2$ & - & - & - & 10.05 \\
\hline 6 Thoralus cranchii & $3: 0.3$ & $11 \quad 2.4$ & $18 * 4.2$ & $17 \quad 6.2$ & $17 * 3.4$ & 10.3 & $64 \quad 3.25$ \\
\hline 7 Eualus occultus & - & $5 \quad 1.1$ & - & $2^{*} 0.2$ & - & - & $7 \quad 0.36$ \\
\hline 8 Lysmata seticaudata & 30.3 & 10.2 & $4 \quad 0.9$ & 10.1 & $8 \quad 1.6$ & - & $14 \quad 0.71$ \\
\hline 9 Gnathophyllum elegans & 10.1 & - & $1 \quad 0.2$ & - & - & 31.0 & $4 \quad 0.20$ \\
\hline 10 Brachycarpus biunguiculatus & - & - & $1 \quad 0.2$ & - & $1 \quad 0.2$ & - & 20.10 \\
\hline 12 Athanas nitescens & $86 \quad 9.3$ & 132.8 & $24 * 5.6$ & 238.3 & $52 * 10.3$ & $76 \quad 24.7$ & $188 \quad 9.54$ \\
\hline 13 Alpheus macrocheles & 10.1 & - & $2 * 0.5$ & 10.1 & 20.4 & $5 \quad 1.6$ & 10) 0.51 \\
\hline 14 A. dentipes & $54 * 5.9$ & $24 * 5.3$ & $10^{*} 2.3$ & $35^{*} 12.7$ & $52 * 10.3$ & $23 * 7.5$ & $144 \quad 7.31$ \\
\hline 15 Synalpheus hululensis & - & $5 * 1.1$ & - & - & - & - & $5 \quad 0.25$ \\
\hline 16 S. gambarelloides & - & 20.4 & - & - & - & - & 20.10 \\
\hline 19 Galathea squamifera & - & - & - & - & $1 \quad 0.2$ & - & $1 \quad 0.05$ \\
\hline $20 \quad$ G. bolivari & $35 * 3.8$ & $15 * 3,3$ & $11 * 2.6$ & $13 * 4.7$ & $15 * 3.0$ & $11 \quad 3.6$ & 653.30 \\
\hline 21 Porcellana platycheles & - & $15 * 3.3$ & - & - & - & - & $15 \quad 0.76$ \\
\hline 22 Pisidia longicornis & $49 * 5.3$ & $23 * 5.0$ & $23 * 5.4$ & $19 \quad 6.9$ & $30 \quad 6.0$ & $24 \quad 7.8$ & $119 \quad 6.04$ \\
\hline 23 Pagurus anachoretus & $5 \quad 0.5$ & $1 \quad 0.2$ & $\begin{array}{ll}3 & 0.7\end{array}$ & $\begin{array}{ll}1 & 0.1\end{array}$ & 20.4 & 10.3 & $8 \quad 0.41$ \\
\hline 24 Cestopagurus timidus & $172 * 18.7$ & $198 * 43.3$ & $164 * 38.5$ & $112 * 40.6$ & $218 * 43.3$ & $78 * 25.3$ & $770 \quad 39.09$ \\
\hline 25 Calcinus tubularis & $453 \quad 49.2$ & $104 \quad 22.8$ & $146 \quad 34.3$ & $43 * 15.6$ & $60 \quad 11.9$ & $51 \quad 16.6$ & $404 \quad 20.51$ \\
\hline 26 Upogebia deltaura & - & - & - & - & - & 20.6 & 20.10 \\
\hline 27 Dromia personata & - & 10.2 & - & - & - & - & 10.05 \\
\hline 29 Ebalia edwardsi & - & - & - & 10.1 & - & - & 10.05 \\
\hline 31 Sirpus zariquieyi & - & $2 * 0.4$ & - & 10.1 & 102 & 20.6 & $6 \quad 0.30$ \\
\hline 32 Xantho incisus & $4 \quad 0.4$ & - & $1 \quad 0.2$ & - & - & - & 10.05 \\
\hline 35 Pilumnus hirtellus & $35 \quad 3.8$ & $21 \quad 4.6$ & $8 * 1.9$ & $3 * 1.1$ & $13 * 2.6$ & 237.5 & $68 \quad 3.45$ \\
\hline 36 P. villosissimus & $5 \quad 0.5$ & $8 \quad 1.8$ & - & 10.1 & $19 \quad 3.8$ & $\begin{array}{ll}4 & 1.3\end{array}$ & $32 \quad 1.62$ \\
\hline 37 Paractaea monodi & - & - & 10.2 & - & - & - & 10.05 \\
\hline 38 Herbstia condyliata & 20.2 & $6 \quad 1.3$ & 10.2 & - & $4 \quad 0.8$ & $1 \quad 0.3$ & $12 \quad 0.61$ \\
\hline 39 Eurynome spinosa & - & - & - & - & - & 10.3 & $1 \quad 0.05$ \\
\hline 40 Acanthonyx lunulatus & - & 20.4 & $4 \quad 0.9$ & 10.1 & 20.4 & - & $9 \quad 0.46$ \\
\hline 41 Pisa nodipes & - & - & - & 10.1 & 10.2 & - & 20.10 \\
\hline 42 P.tetraodon & - & - & - & 10.1 & - & - & l $\quad 0.05$ \\
\hline 46 Achaeus cranchii & $9 * 1.0$ & - & - & - & $1 \quad 0.2$ & 20.6 & 30.15 \\
\hline 47 Maja crispata & - & - & - & - & $1 \quad 0.2$ & - & $1 \quad 0.05$ \\
\hline 48 Inachus phalangium & - & - & $1 * 0.2$ & - & - & - & 10.05 \\
\hline 49 Macrocopia czemiavskii & 30.3 & - & - & - & - & - & - \\
\hline $50 \quad M$. longirostris & - & - & $1 \quad 0.2$ & - & - & - & 10.05 \\
\hline Total dry weight Posidonia $(\mathrm{g})$ & 1102.3 & 949.7 & 753.8 & 925.6 & 1223.8 & 1051.6 & 4904.5 \\
\hline $\mathrm{N}$ total & 920 & 457 & 426 & 276 & 5013 & 308 & 1970 \\
\hline $\mathrm{N}$ in $1000 \mathrm{~g}$ & 835 & 481 & 565 & 298 & 411 & 293 & $4(1) 2$ \\
\hline Richness (S) & 17 & 19 & 21 & 18 & 21 & 17 & 36 \\
\hline Diversity $\left(\mathrm{H}^{\prime}\right)$ & 2.40 & 2.74 & 2.48 & 2.73 & 2.84 & 2.94 & \\
\hline Equitability $\left(\mathrm{J}^{\prime}\right)$ & 0.59 & 0.65 & 0.56 & 0.65 & 0.65 & 0.72 & \\
\hline
\end{tabular}


Table 2. Faunistic survey of 1987. For explanations see Table 1.

\begin{tabular}{|c|c|c|c|c|c|c|c|c|c|c|}
\hline \multirow{2}{*}{$\frac{1987}{1}$} & \multirow{2}{*}{$\underbrace{7 \text { day/month }}_{\text {Processa edulis }}$} & \multicolumn{2}{|r|}{$8 / 1$} & \multicolumn{2}{|c|}{$5 / 2$} & $10 / 4$ & $\begin{array}{l}5-7 m \\
25 / 8\end{array}$ & $7 / 10$ & $15 / 12$ & Total 3-4m \\
\hline & & - & & - & & 10.2 & - & - & - & 10.03 \\
\hline 3 & P. nouveli & - & & - & & $1 \quad 0.2$ & - & - & - & 10.03 \\
\hline 4 & Hippolyte inermis & - & & - & & - & - & 10.1 & - & 10.03 \\
\hline 5 & H. longirostris & - & & 1 & 0.2 & - & - & - & - & 10.03 \\
\hline 6 & Thoralus cranchii & 12 & 1.6 & 23 & 4.0 & $24 * 5.6$ & $21 * 3.8$ & - & $18 \quad 2.6$ & $98 \quad 2.65$ \\
\hline 7 & Eualus occultus & 1 & 0.1 & - & & - & - & - & - & 10.03 \\
\hline 8 & Lysmata seticaudata & 2 & 0.3 & - & & 10.2 & $\begin{array}{ll}4 & 0.7\end{array}$ & 10.1 & 20.3 & $10 \quad 0.27$ \\
\hline 9 & Gnathophyllum elegans & - & & 2 & 0.4 & - & - & 10.1 & - & 30.08 \\
\hline 10 & Brachycarpus biunguiculatus & 2 & 0.3 & 1 & 0.2 & 10.2 & - & - & - & 40.11 \\
\hline 11 & Typton spongicola & - & & 1 & 0.2 & - & - & - & - & 10.03 \\
\hline 12 & Athanas nitescens & 191 & 26.2 & 1061 & 18.6 & $65 * 15.0$ & $75 * 13.6$ & $64 * 8.9$ & $118 \quad 17.0$ & 61916.75 \\
\hline 13 & Alpheus macrocheles & 7 & 1.0 & 6 & 1.1 & - & 10.2 & $3 * 0.4$ & $9 \quad 1.3$ & $26 \quad 0.70$ \\
\hline 14 & A. dentipes & $25^{*}$ & $* 3.4$ & $29^{*}$ & 5.1 & $30 * 6.9$ & $37 * 6.7$ & $28 * 3.9$ & $46 \quad 6.6$ & $195 \quad 5.28$ \\
\hline 17 & Pontonia pinnophylax & - & & - & & - & - & 10.1 & - & 10.03 \\
\hline 18 & Scyllarus pygmaeus & - & & 1 & 0.2 & - & - & 10.1 & - & 20.05 \\
\hline 19 & Galathea squamifera & 1 & 0.1 & 2 & 0.4 & - & 10.2 & $8 \quad 1.1$ & 10.1 & 130.35 \\
\hline 20 & G. bolivari & 18 & 2.5 & $15^{*}$ & 2.6 & $31 * 7.2$ & $48^{*} 8.7$ & $15 * 2.1$ & $30 \quad 4.3$ & $157 \quad 4.25$ \\
\hline 22 & Pisidia longicornis & 34 & 4.7 & 45 & 7.9 & $47 * 10.9$ & $54 * 9.8$ & $84 * 11.7$ & 537.6 & 3178.58 \\
\hline 23 & Pagurus anachoretus & 9 & 1.2 & 3 & 0.5 & $\begin{array}{ll}3 & 0.7\end{array}$ & - & $5 * 0.7$ & $7 \quad 1.0$ & 270.73 \\
\hline 24 & Cestopagurus timidus & 215 & 29.5 & $214^{*} 3$ & 37.6 & $115 * 26.6$ & $154 * 27.8$ & $256 * 35.6$ & $188 \quad 27.1$ & 114230.91 \\
\hline 25 & Calcinus tubularis & 155 & 21.3 & 831 & 14.6 & $\begin{array}{ll}79 & 18.3\end{array}$ & $134 * 24.2$ & $199 * 27.7$ & 16123.2 & 81121.95 \\
\hline 26 & Upogebia deltaura & 1 & 0.1 & - & & - & - & - & - & 10.03 \\
\hline 27 & Dromia personata & - & & 1 & 0.2 & - & - & 10.1 & - & 20.05 \\
\hline 28 & Ebalia deshayesi & 1 & 0.1 & 1 & 0.2 & - & - & - & - & 20.05 \\
\hline 29 & E.edwardsi & - & & - & & - & - & 10.1 & - & 10.03 \\
\hline 30 & Ilia nucleus & - & & $1 \mathrm{r}$ & 0.2 & - & - & $1 \mathrm{r} 0.1$ & - & 20.05 \\
\hline 31 & Sirpus zariquieyi & 1 & 0.1 & - & & - & - & - & - & 10.03 \\
\hline 32 & Xantho incisus & - & & 1 & 0.2 & - & - & 10.1 & $4 \quad 0.6$ & 60.16 \\
\hline 33 & $X$. pilipes & - & & - & & 10.2 & - & - & - & 10.03 \\
\hline 34 & Pinnotheres pisum & - & & - & & - & - & $1 * 0.1$ & - & 10.03 \\
\hline 35 & Pilumnus hirtellus & 43 & 5.9 & 28 & 4.9 & $22 \quad 5.1$ & $18 * 3.2$ & $30 * 4.2$ & $25 \quad 3.6$ & $166 \quad 4.49$ \\
\hline 36 & P. villosissimas & 2 & 0.3 & 1 & 0.2 & 71.6 & $4 \quad 0.7$ & $4 \quad 0.6$ & $11 \quad 1.6$ & $29 \quad 0.78$ \\
\hline 37 & Paractaea monodi & 1 & 0.1 & 2 & 0.4 & - & - & - & - & 30.08 \\
\hline 38 & Herbstia condyliata & - & & - & & 10.2 & - & $4 \quad 0.6$ & - & $\begin{array}{ll}5 & 0.14\end{array}$ \\
\hline 40 & Acanthonyx lunulatus & 1 & 0.1 & - & & 10.2 & - & $3 \quad 0.4$ & - & 50.14 \\
\hline 41 & Pisa nodipes & - & & - & & - & - & - & 10.1 & 10.03 \\
\hline 42 & P. tetraodon & - & & - & & - & 10.2 & - & 10.1 & 20.05 \\
\hline 43 & P. cf. carinimama & 3 & 0.4 & - & & - & - & 10.1 & - & 40.11 \\
\hline 44 & P. muscosa & - & & - & & - & - & - & 10.1 & 10.03 \\
\hline 45 & Achaeus gracilis & - & & 2 & 0.4 & 20.5 & - & $1 * 0.1$ & 10.1 & 60.16 \\
\hline & A. cranchii & 4 & 0.5 & - & & - & 10.2 & $4 * 0.6$ & $16 \quad 2.3$ & 250.68 \\
\hline Tota & al dry weight Posidonia (g) & 1643 & & 1371.9 & & 1372.7 & 953.3 & 1013.6 & 1204.3 & 7559.3 \\
\hline & total & 729 & & 569 & & 432 & 553 & 719 & 693 & 3695 \\
\hline & in $1000 \mathrm{~g}$ & 44 & & 415 & & 315 & 580 & 709 & 575 & 489 \\
\hline & ichness (S) & 22 & & 23 & & 18 & 14 & 26 & 19 & 41 \\
\hline & diversity $\left(\mathrm{H}^{\prime}\right)$ & & .72 & & .80 & 3.03 & 2.80 & 2.68 & 2.99 & \\
\hline & quitability $\left(\mathrm{J}^{\prime}\right)$ & & 1.61 & & 62 & 0.73 & 0.74 & 0.57 & 0.70 & \\
\hline
\end{tabular}


Table 3. General composition of the Posidonia - Decapoda community. Absolute and relative abundances of all species in the samples.

\begin{tabular}{|c|c|c|c|c|c|c|c|}
\hline & & $\mathbf{N}^{\circ}$ & $\%$ & & & $\mathbf{N}^{\circ}$ & $\%$ \\
\hline 1 & $\begin{array}{l}\text { Processa edulis } \\
\text { (RIsso, 1816) }\end{array}$ & 1 & 0.02 & 2 & $\begin{array}{l}\text { P. macrophthalma } \\
\text { Nouvel \& Holthus, } 1957\end{array}$ & 4 & 0.06 \\
\hline 3 & $\begin{array}{l}\text { P. nouveli } \\
\text { Al-ADHUB \& Williamson, } 1975\end{array}$ & 1 & 0.02 & 4 & $\begin{array}{l}\text { Hippolyte inermis } \\
\text { LEACH, } 1815\end{array}$ & 1 & 0.02 \\
\hline 5 & $\begin{array}{l}\text { H. longirostris } \\
\text { (CZERNIAVSKY, 1868) }\end{array}$ & 2 & 0.03 & 6 & $\begin{array}{l}\text { Thoralus cranchii } \\
\text { (LEACH, 1817) }\end{array}$ & 165 & 2.5 \\
\hline 7 & $\begin{array}{l}\text { Eualus occultus } \\
\text { (LeBour, 1936) }\end{array}$ & 8 & 0.1 & 8 & $\begin{array}{l}\text { Lysmata seticaudata } \\
\text { (Risso, 1816) }\end{array}$ & 27 & 0.4 \\
\hline 9 & $\begin{array}{l}\text { Gnathophyllum elegans } \\
\text { (Risso, 1816) }\end{array}$ & 8 & 0.1 & 10 & $\begin{array}{l}\text { Brachycarpus biunguiculatus } \\
\text { (LuCAS, 1846) }\end{array}$ & 6 & 0.09 \\
\hline 11 & $\begin{array}{l}\text { Typton spongicola } \\
\text { Costa, } 1844\end{array}$ & 1 & 0.02 & 12 & $\begin{array}{l}\text { Athanas nitescens } \\
\text { (LEACH, 1814) }\end{array}$ & 893 & 13.6 \\
\hline 13 & $\begin{array}{l}\text { Alpheus macrocheles } \\
\text { (HALISTONE, 1835) }\end{array}$ & 37 & 0.6 & 14 & $\begin{array}{l}\text { A. dentipes } \\
\text { GuÉRIN, } 1832\end{array}$ & 393 & 6.0 \\
\hline 15 & $\begin{array}{l}\text { Synalpheus hululensis } \\
\text { CouTIÈRE, } 1908\end{array}$ & 5 & 0.07 & 16 & $\begin{array}{l}\text { S. gambarelloides } \\
\text { (NARDo, 1847) }\end{array}$ & 2 & 0.03 \\
\hline 17 & $\begin{array}{l}\text { Pontonia pinnophylax } \\
(\text { OTro, } 1821)\end{array}$ & 1 & 0.02 & 18 & $\begin{array}{l}\text { Scyllarus pygmaeus } \\
\text { (BATE, 1888) }\end{array}$ & 2 & 0.03 \\
\hline 26 & $\begin{array}{l}\text { Upogebia deltaura } \\
\text { (LEACH, 1815) }\end{array}$ & 3 & 0.05 & 19 & $\begin{array}{l}\text { Galathea squamifera } \\
\text { LEACH, } 1814\end{array}$ & 14 & 0.2 \\
\hline 20 & $\begin{array}{l}\text { G. bolivari } \\
\text { ZARIQUIEY A., } 1950\end{array}$ & 257 & 3.9 & 21 & $\begin{array}{l}\text { Porcellana platycheles } \\
\text { (PENNANT, 1777) }\end{array}$ & 15 & 0.2 \\
\hline 22 & $\begin{array}{l}\text { Pisidia longicornis } \\
\text { (LINNAEUS, 1767) }\end{array}$ & 485 & 7.4 & 23 & $\begin{array}{l}\text { Pagurus anachoretus } \\
\text { Risso, } 1827\end{array}$ & 40 & 0.6 \\
\hline 24 & $\begin{array}{l}\text { Cestopagurus timidus } \\
\text { (Roux, 1830) }\end{array}$ & 2084 & 31.6 & 25 & $\begin{array}{l}\text { Calcinus tubularis } \\
\text { (LINNAEUS, } 1767 \text { ) }\end{array}$ & 1668 & 25.3 \\
\hline 27 & $\begin{array}{l}\text { Dromia personata } \\
\text { (LINNAEUS, } 1758 \text { ) }\end{array}$ & 3 & 0.05 & 28 & $\begin{array}{l}\text { Ebalia deshayesi } \\
\text { LuCAs, } 1846\end{array}$ & 2 & 0.03 \\
\hline 29 & $\begin{array}{l}\text { E.edwardsi } \\
\text { CostA, } 1838\end{array}$ & 2 & 0.03 & 30 & $\begin{array}{l}\text { Ilia nucleus } \\
\text { (LinNAEUs, 1758) }\end{array}$ & 2 & 0.03 \\
\hline 31 & $\begin{array}{l}\text { Sirpus zariquieyi } \\
\text { GORDON. } 1953\end{array}$ & 7 & 0.1 & 32 & $\begin{array}{l}\text { Xantho incisus } \\
\text { (LEACH, 1814) }\end{array}$ & 11 & 0.2 \\
\hline 33 & $\begin{array}{l}X \text {.pilipes } \\
\text { A. MiLNE EDWARDS, } 1867\end{array}$ & 1 & 0.02 & 34 & $\begin{array}{l}\text { Pinnotheres pisum } \\
\text { (LINNAEUS, } 1767 \text { ) }\end{array}$ & 1 & 0.02 \\
\hline 35 & $\begin{array}{l}\text { Pilumnus hirtellus } \\
\text { (LinnaEus, 1761) }\end{array}$ & 269 & 4.1 & 36 & $\begin{array}{l}\text { P. villosissimus } \\
\text { (RAFINESQUE, 1814) }\end{array}$ & 66 & 1.0 \\
\hline 37 & $\begin{array}{l}\text { Paractaea monodi } \\
\text { Guinot, } 1969\end{array}$ & 4 & 0.06 & 38 & $\begin{array}{l}\text { Herbstia condyliata } \\
\text { (FABRICIUS, 1787) }\end{array}$ & 19 & 0.3 \\
\hline 39 & $\begin{array}{l}\text { Eurynome spinosa } \\
\text { HAILSTONE, } 1835\end{array}$ & 1 & 0.02 & 40 & $\begin{array}{l}\text { Acanthonyx lunulatus } \\
\text { (Risso, 1816) }\end{array}$ & 14 & 0.2 \\
\hline 41 & $\begin{array}{l}\text { Pisa nodipes } \\
\text { (LEACH, 1815) }\end{array}$ & 3 & 0.05 & 42 & $\begin{array}{l}\text { P. tetraodon } \\
\text { (PenNant, 1777) }\end{array}$ & 3 & 0.05 \\
\hline 43 & $\begin{array}{l}\text { P. cf. carinimana } \\
\text { MIERS, } 1879\end{array}$ & 4 & 0.06 & 44 & $\begin{array}{l}\text { P. muscosa } \\
\text { (LiNNAEUS, 1758) }\end{array}$ & 1 & 0.02 \\
\hline 45 & $\begin{array}{l}\text { Achaeus gracilis } \\
\text { (CosTA, 1839) }\end{array}$ & 6 & 0.09 & 46 & $\begin{array}{l}\text { A. cranchii } \\
\text { LEACH, } 1817\end{array}$ & 37 & 0.6 \\
\hline 47 & $\begin{array}{l}\text { Maja crispata } \\
\text { Risso, } 1827\end{array}$ & 1 & 0.02 & 48 & $\begin{array}{l}\text { Inachus phalangium } \\
\text { (FABRICIUS, 1775) }\end{array}$ & 1 & 0.02 \\
\hline 49 & $\begin{array}{l}\text { Macrocopia czerniavskii } \\
\text { (BRANDT, } 1880 \text { ) }\end{array}$ & 3 & 0.05 & 50 & $\begin{array}{l}\text { M. longirostris } \\
\text { (FABRICIUS, 1775) }\end{array}$ & 1 & 0.02 \\
\hline
\end{tabular}

Total: Caridea + Palinuridea $23.6 \%$ 


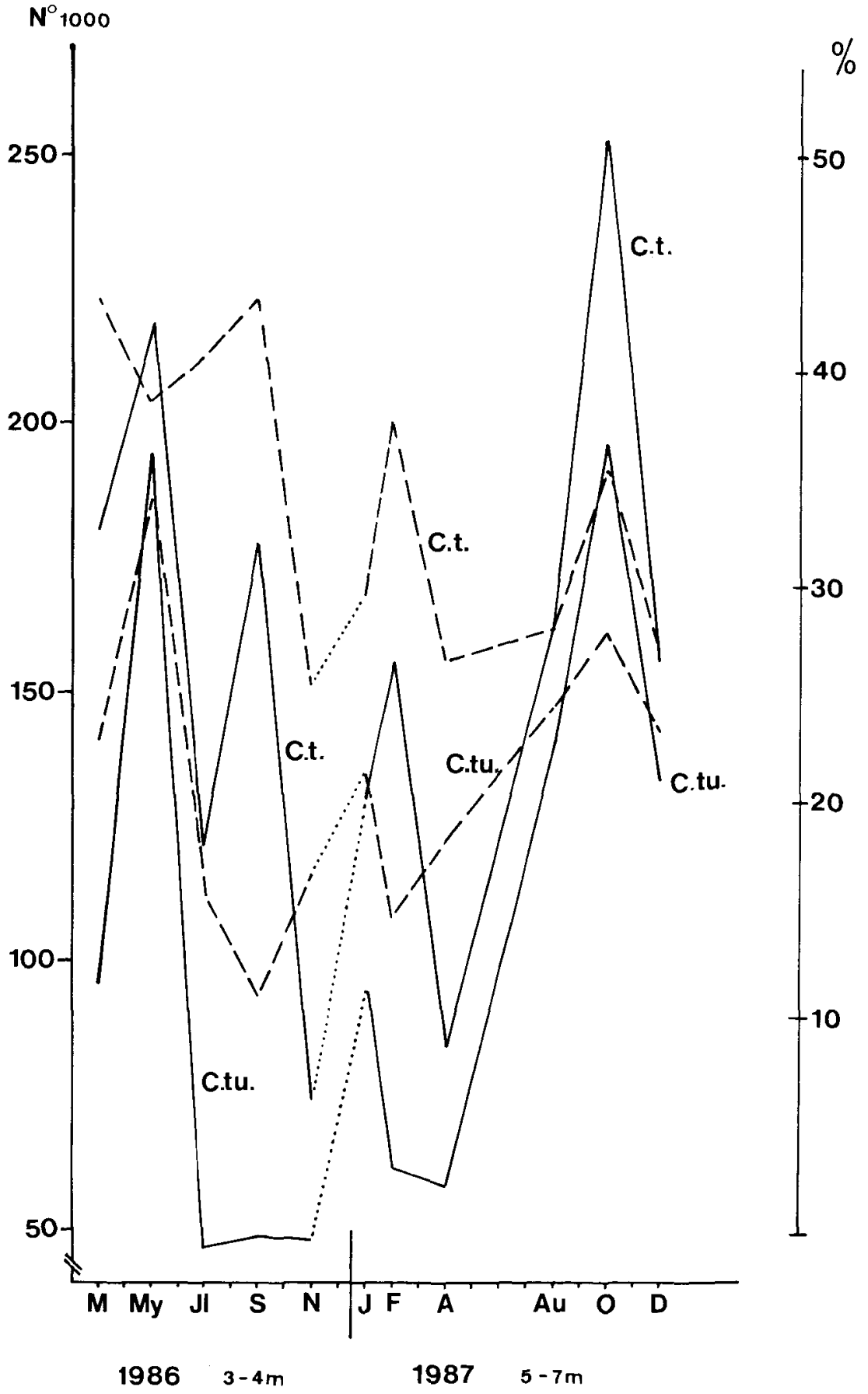

Fig. 4. Evolution of abundance of the two dominant hermit crabs, Cestopagurus timidus (C.t.) and Calcinus rubularis (C. tu.). Continuous lines: absolute abundances (referred to $1000 \mathrm{~g}$ dry weight of sample); broken lines: relative abundances. 
Of these, only the first 7 (Fig. 2) are present in all the samples; the last two species, together with Pagurus anachoretus, are absent in one sample.

The hermit crabs Cestopagurus timidus and Calcinus tubularis clearly dominate (Fig. 2, Tables 1, 2). Thus, the variations in their abundances (Fig. 4) determine variation of the entire taxocoenosis (Fig. 3).

The absolute abundances of both species follow the same pattern, except for shallower samples during the minimum foliar period (summer and autumn), in which an apparently closer relationship between C. tubularis and dry weight of leaf exists. However, the correlation between both is low (0.46) and not significant.

C. timidus is slightly more dominant on shallow bottoms, while C. tubularis increases in abundance with depth, where the hydrodynamism is less pronounced. This is most obvious in the two March 1986 samples, which were taken near the minimum $(3 \mathrm{~m})$ and maximum depth $(9 \mathrm{~m})$ of the meadow; it is somewhat less clear in the overall two year study since the difference in depth (3-4 $\mathrm{m}$ and $5-7 \mathrm{~m}$, respectively) was less.

With respect to other species represented in all samples and having a relative abundance higher than $5 \%$ :

A. nitescens (together with $C$. tubularis) seems to prefer less hydrodynamic bottoms. Nevertheless, this species increases in number in autumn (more obvious at 3-4 $\mathrm{m}$ ) and winter (especially at 5-7 $\mathrm{m}$ ) after the reproductive period. This coincides with the data obtained from calcareous bottoms (GARCía-RAso \& Fernandez, 1987). The number of P. longicornis specimens increases in summer and autumn and is slightly higher at $5-7 \mathrm{~m}$ (for taxonomic considerations see García-Raso, 1987). A. dentipes has a somewhat lower relative abundance than on shallow calcareous bottoms.

\section{b. Reproduction}

In the more abundant species such as C.timidus, A. dentipes, and G. bolivari, ovigerous females are present nearly throughout the year. However, they seem to be lacking or are reduced in number at the end and at the beginning of each year; this is more pronounced in A. nitescens (April-October) and even more so in C. tubularis (from July to October).

On the other hand, the greater abundance of minute specimens, in certain months, allows us to detect maximum recruitment of the different species. For C. timidus this appears to be September and for G. bolivari July-August. With regard to species with lower population densities, very small specimens of Sirpus zariquieyi and Acanthonyx lunulatus appear in July, while Achaeus cranchii appears in December and Paractaea monodi in January-February (the carapace areas were not well defined in the smallest).

As is the case for the seaweed $M$. lichenoides in shallow calcareous bottoms, the studied Posidonia bed is a habitat essentially functioning as a nursery and for early development (GARcía-RAso, 1988). The vast majority of decapods are thus young or small specimens. 
c. Other biological data

On the use of gastropod shells by hermit crabs: The dominant species, C. timidus, chooses medium-sized Bittium shells, mainly B. reticulatum (DA Costa, 1778). Living $B$. reticulatum are fairly scarce in the studied samples. For this reason, either horizontal or vertical movement in search of suitable shells is probable. Zupi et al. (1985) conclude that vertical migration takes place. However, B. reticulatum has a wide bathymetric range and inhabits various biotopes, preferably Cymodocea (TEMPLADo, 1982) and calcareous bottoms (Hergueta, pers. comm.).

C. tubularis, like C.timidus, seems to prefer shells of Bittium and Hinia; however, it appears to be less selective because it also frequently occupies other shells. Two interesting examples are Columbella rustica (whose interior can be shared with living specimens of Crepidula) and Vermetus sp. (two specimens with hermit crab occupants); neither were ever occupied in the study area by C. timidus.

With regard to parasitism, rhizocephalans and bopyrids were rare. Bopyrids infested only 3 species: G. bolivari (7 specimens: March 1986, January 1987, April 1987, and August 1987), P. longicornis (1 specimen from August 1987), and H. longirostris (1 specimen). Rhizocephalans parasitized 3 specimens of C. timidus.

\section{Taxocoenosis structure}

Diversity ranged from 2.40 to 3.03 , depending more on equitability than on richness (Tables 1, 2 and Fig. 5). In fact, the hermit crabs' maximum (representing $56.9 \%$ ) coincides with minimum diversity and equitability.

Richness varied from 17 to 26, being higher than on calcareous bottoms (García-Raso \& Fernandez, 1987; García-Raso, 1988) with a similar taxacoenosis. Richness and equitability are higher and fluctuate more at 5-7 m.

The dominance-diversity curves (Fig. 6a, b) are more or less similar to the coralligenous curves (GARCíA-RAso, 1988), although perhaps somewhat less geometrical.

Similarity between samples. Samples could be arranged into four groups (Fig. 7). These are related to variations both in diversity and in equitability (see Fig. 5 and Tables 1 and 2), which, as has been shown, largely depend on the abundances or the recruitment of the dominant species. Therefore, the first "quadrant" includes the two months (group A) of maximum recruitment of the two dominant hermit crabs of both studied cycles (Fig. 4), which present the minimum diversity and equitability (Fig. 5). The opposite "quadrant" contains group B - the months of both years which have the opposite characteristics (maximum equitability and diversity), i.e., minima or average abundances in both dominant species. Groups $\mathrm{C}$ and $\mathrm{D}$ show middle values. Nevertheless, $\mathrm{C}$ shares (together with A) the positive side of the "axis", since this group contains the months having a maximum abundance of one of the two dominant hermit crab species and of $A$. nitescens (the third dominant species). 
If the same analysis is carried out for the 7 dominant species alone (Fig. 8) the ones controlling the system - and the samples are studied seasonally, a clear seasonality is evident in 1986. This is less obvious in 1987. This seasonality mainly pertains to the set of shallower samples in which the external ambient variations and especially hydrodynamism have a greater influence. This influence is higher in summer and autumn and appears to affect the shallower leaves (Fig. 1) and C. tubularis abundance (Fig. 4).

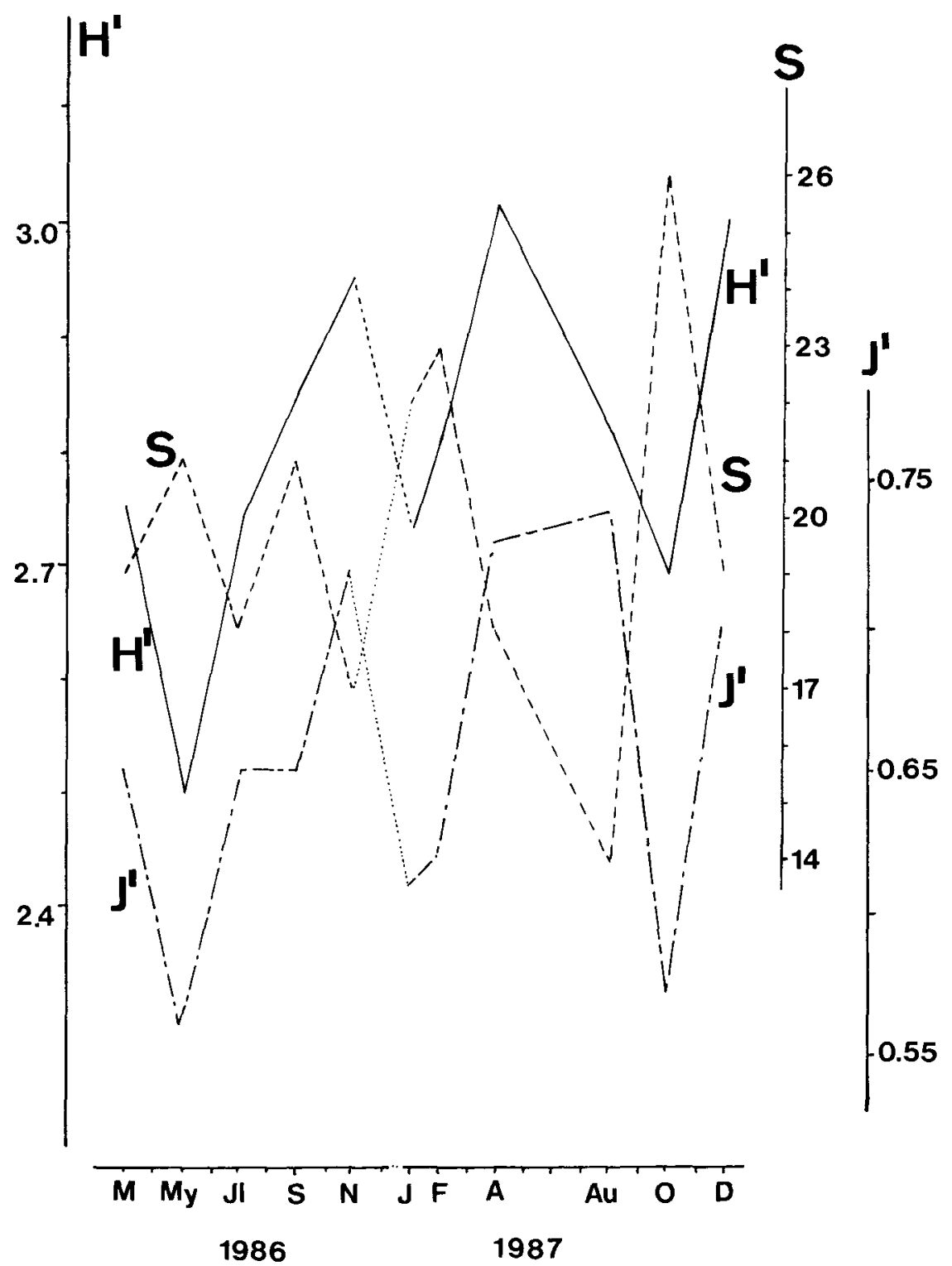

Fig. 5. Evolution of diversity $\left(\mathrm{H}^{\prime}\right)$, equitability $\left(J^{\prime}\right)$, and richness $(\mathrm{S})$ during the studied years. 

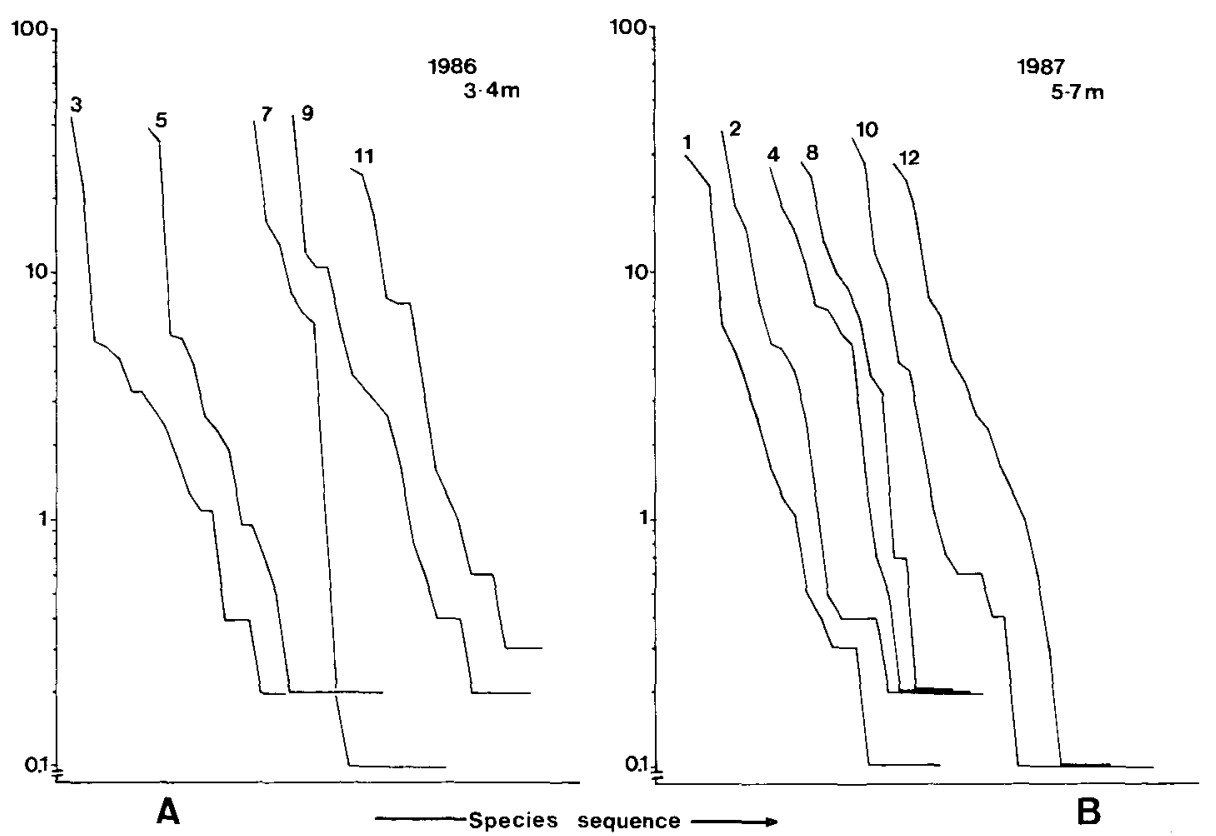

Fig. 6. Monthly dominance-diversity curves during: A. 1986 at 3-4m, and B. 1987 at 5-7m (1: January, ... 12: Deccmber).

\section{Discussion}

The comparison of our foliar area data with those obtained from other Posidonia studies (Romero, 1985), shows coinciding tendencies.

The differences found between the two cycles are probably due, at least in part, to depth, since in the most superficial area, hydrodynamism can affect leaf development or increase leaf loss. In fact our observations indicate that strong Levante winds do the most harm in the area in summer and autumn.

Faunistically, our sample data differed from those reported in other studies (Harmelin, 1964; Ledoyer, 1966; Carbonell, 1984; Templado, 1984 b) in that:

1. Our samples were characterized by greater specific richness and abundance. This, we believe, is due to (a) the investigations covering annual cycles, (b) the method of sampling, and (c) the use of a fine mesh in the separation of specimens in the laboratory. This approach enabled us to capture all the species that spend all or part of their lives in the rhizomes, and to retain the majority (if not all) of the specimens in the samples. Thus, while densities of 500-700 indivs. - $\mathrm{m}^{-2}$ have been reported (KıкUCHI, 1980) for the rhizome layer of Posidonia oceanica from the Gulf of Naples, our samples contained up to more than 900 indivs. $0.09 \mathrm{~m}^{2}$.

2. The decapod species considered to be characteristic of Posidonia, i.e., those able to rest on leaves such as Hippolyte inermis and H.longirostris, have little quantitative importance in the overall decapod community in the meadow 


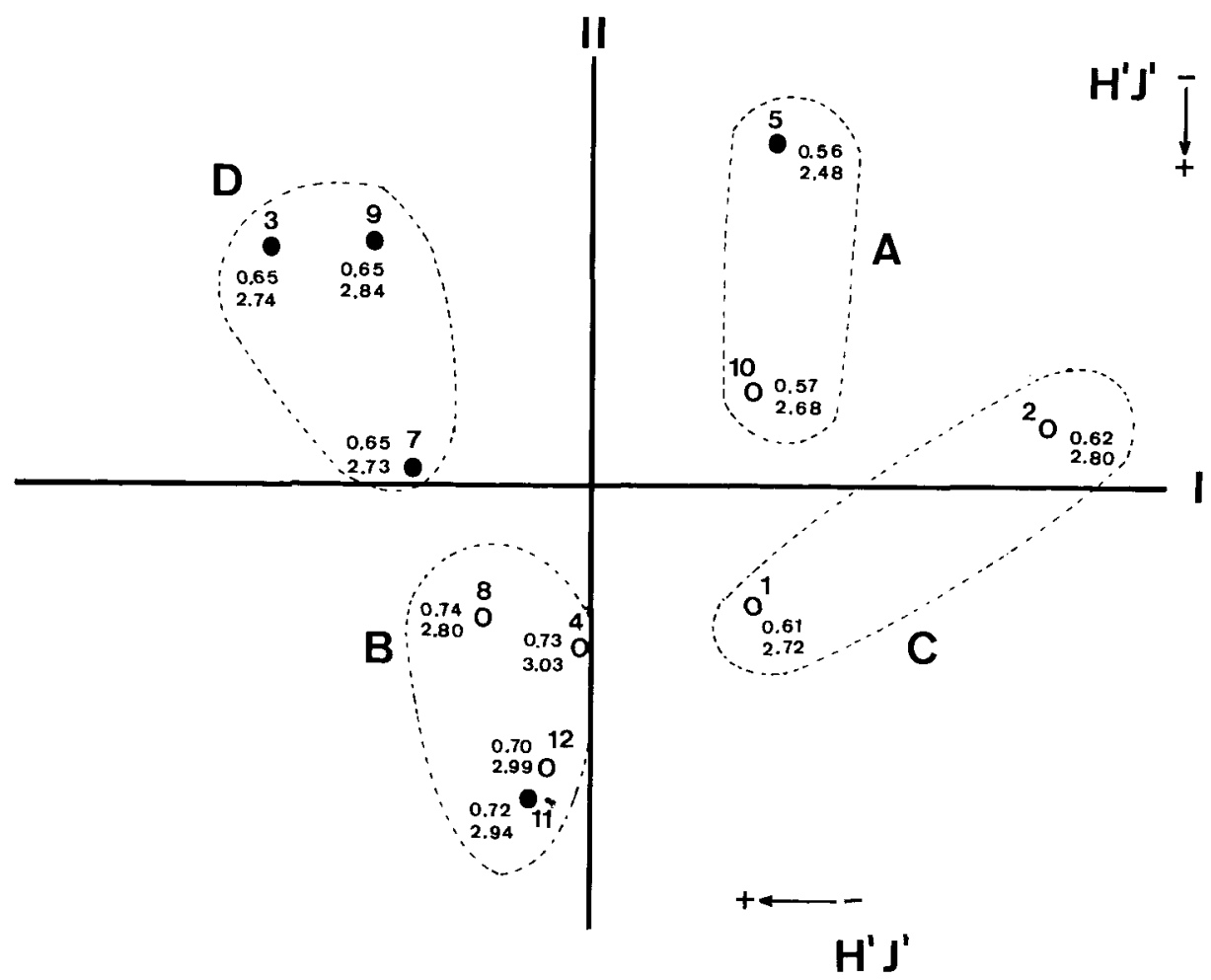

Fig. 7. Similarity between monthly samples (1: January, ..., 12: December; black circles: 1986. white circles: 1987). Analysis of principal coordinates (Q mode). Percentage residual 68.8 .

and are restricted to the foliar stratum. In fact, the number of specimens captured in $12 \mathrm{~m}^{2}$ (using a net, at a depth of 6-9 $\mathrm{m}$ ), was: 16 specimens of $H$. inermis and 1 of $H$. longirostris. In comparison, a much smaller sample $\left(0.09 \mathrm{~m}^{2}\right)$ may contain more than 400 hermit crabs.

The same holds true for other Natantia belonging to genera Palaemon and Processa, although their abundances are even lower (see Tables) and no specimens were caught on the leaves during the day. Other studies show that the latter are only found, or are found at least in greater numbers, at night (LEIOYER, 1966; KIKUCHI, 1980) (day-night differences are also known in other groups, Templado, 1982; Russo et al., 1983). These natantians must originate either from (a) deeper bottoms, which we have not studied, or (b) adjacent habitats (as demonstrated for other groups, SPADA, 1971; PEREIRA, 1981). The above species would thus use the meadow as a hunting or feeding ground in their phase of nocturnal activity (CHFSSA et al., 1985; ZUPI \& FrESI, 1985).

The taxocoenosis of the studied Posidonia beds and that of the seaweed M. lichenoides (Ellis \& Sol..) Lemoine (García-Raso \& Fernandez, 1987; GARCíA-RAso, 1988) are qualitatively very similar. The dominant species are the same; only the order of dominance changes, the dominant species being the two hermit crabs C.timidus and C. tubularis. 
In comparison with calcareous bottoms, the higher richness in Posidonia is perhaps not surprising: it is a much more open system, with less limitations (space, food resources), and in which at least two different strata (leaves and rhizomes) can be defined.

The superficial calcareous bottoms cited above have more limitations and are more uniform. This results in higher competitive pressure for the resources in general and subsequently a repartition of these (more obvious in the samples from Málaga; García-Raso \& Fernandez, 1987). Thus, the dominant species that spend their lives in this biotope show different morphologies and adaptations; a synchronization probably exists. More or less the same happens between the dominant species in the studied Posidonia meadows, only the two abundant hermit crabs being anatomically similar. Perhaps they utilize different

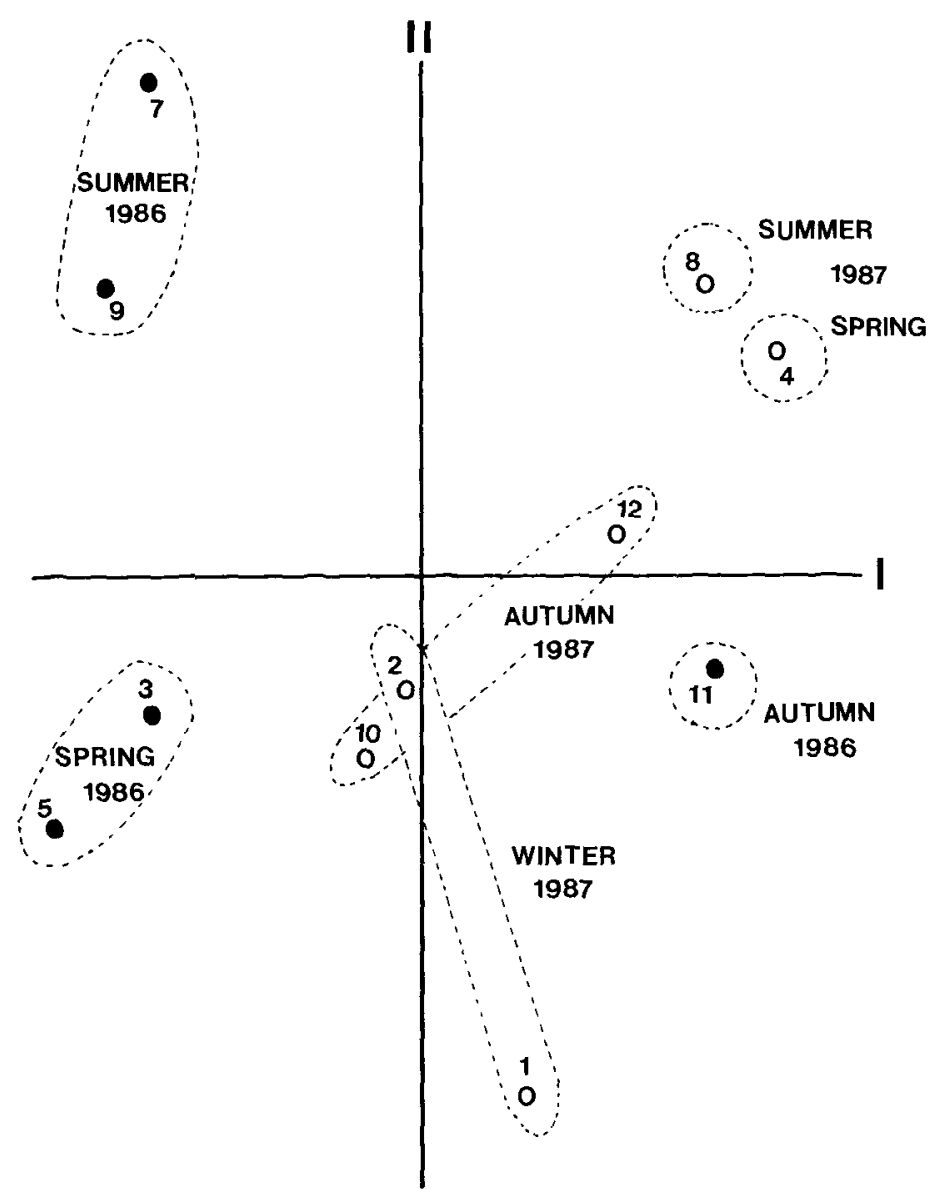

Fig. 8. Similarity between monthly samples (1: January, .., 12: Decomber; black circles: 1986. white circles: 1987). Analysis of principal coordinates (Q mode) with the seven dominant species (percentage residual 52.1). The different seasons in both years are indicated. 
resources or occupy different "niches". So, when the MACARTHUR broken stick model (MacArthur, 1957; Colinvaux, 1973) is applied to the dominant species, and the distances that separate the monthly samples of stable equilibrium (the differences between the chi square and the obtained values) are correlated against species abundance, the higher value $(r=0.6)$ is found in a dominant hermit crab, C. tubularis.

This species prefers deeper bottoms (Table 1: March samples at 3 and $9 \mathrm{~m}$; and Tables 1 and 2: total abundances) and seems to have a closer relationship with the foliar surface. However, the decrease of both C. tubularis (Fig. 4) and the foliar area (Fig. 1) may be completely or partly independant of each other; both may be due to hydrodynamism, which is more pronounced in shallower waters, especially in summer.

The greater and fluctuating richness and equitability at $5-7 \mathrm{~m}$ is probably due to the position towards the centre of the studied meadow where: (a) Posidonia is better developed, (b) the typical community exists (ScIPIONE et al., 1983), and (c) the depth represents a "border" (MARGALEF, 1974) between a shallow and a deep "zone" with different characteristics (hydrodynamism, leaf density, adjacent biotope influence) and, above all, with different relative species abundances. Nevertheless, the differences in richness are minimal and are based (Tables 1 and 2) on species with low population densities.

Differences due to different depth and hydrodynamic conditions have also been found in other groups (Ledover, 1966; Pronzato \& Belloni, 1981; Boero, 1981 a, b; Boero et al., 1985; Russo et al., 1984; Lorenti \& Fresi, 1983; SCIPIONE et al., 1983).

The study of the similarity between monthly samples shows the characteristics of the habitat and the decapod community: an open and shallow system with a high dominance of a few species in which two different strata (leaves and rhizomes) may be defined. The structure of the decapod community, both overall and monthly, is thus controlled by many factors, of which the strongly dominant species and the hydrodynamic conditions (directly or indirectly through the leaves) are most important.

\section{Summary}

A total of 6585 specimens belonging to 50 species were found. However, only 9: Cestopagurus timidus, Calcinus tubularis, Athanas nitescens, Alpheus dentipes, Pisidia longicornis, Pilumnus hirtellus, Galathea bolivari, Thoralus cranchii, and Pilumnus villosissimus have a relative abundance higher than $1 \%$ (totalling $95.4 \%$ ); only the first seven are always present.

In the entire taxocoenosis, the species of the genera Hippolyte and Processagenerally considered to be "typical" for this habitat - have very little quantitative importance. The structure and evolution of the taxocoenosis over time is basically controlled by the two dominant hermit crabs. Their abundances follow the same pattern of development, although this is less obvious in shallower waters in summer and autumn, during which a decrease of $C$. tubularis coincides with a decrease in the foliar area and with stronger hydrodynamic conditions. 
The dominance-diversity curves show a geometrical distribution. The diversity (between 2.4 and 3.03) depends on the equitability. The richness (between 17 to 21) and equitability fluctuate more at 5-7 m, perhaps because this depth lies in the middle of the studied meadow where the typical animal community exists and where a boundary effect might be present. In the study of samples (Q mode), the defined groups show, at least in part, a dependence on the diversityequitability; these are strongly related to the maximum recruitment of the 2 or 3 dominant species and the external environmental fluctuations (hydrodynamic conditions), the latter mainly in the shallower samples.

\section{Acknowledgements}

This study was supported by the C. A. I. C. Y. T., project PR84-0401-C02-01.

\section{References}

Bellan-Santini, D., A. Willsie \& A. Arnoux, 1986: Distribution comparée des Crustacés Amphipodes de la matte d'herbier de Posidonies mort et vivant. Rapp. Comm. int. Mer Mćdit., 30 (2): 8.

Bell, J.D. \& M. L. Harmelin-Vivien, 1983: Fish fauna of French mediterrancan Posidonia oceanica seagrass meadows. 2. Feeding habits. Tethys, 11 (1): 1-14.

BhN, D. van deEr, 1971: Les ćpiphytes des fcuilles de Posidonia oceanica Delile sur les côtes françaises de la Méditerranće. Mem. Inst. Roy, Sc. Nat. Belg., 168: 1-101.

Benmo, J., 1987: Esponjas epibiontes de Posidonia oceanica. Cuad. Marisq. Publ. Téc., 11: $129-142$.

Botro, F., 1981 a: Bathymetric distribution of epifauna of a Posidonia meadow of the Isle of Ischia (Naples): Hydroids. Rapp. Comm. int. Mer Médit. 27 (2): 197-198.

_ - 1981 b: Systematics and ccology of the hydroid population of two Posidonia oceanica meadows. P.S.Z. N. I: Marine Ecology, 2 (3): 181-197.

- - L. Chessa, C. Chimhan \& E. Fresi, 1985: The zonation of epiphytic hydroids on the leaves of some Posidonia oceanica (L.) DeLit. beds in the Central Mediterrancan. P.S. Z. N. I: Marine Ecology, 6 (1): 27-33.

Boudouresque, Ch.-F.. 1968: Contribution à l'étude du peuplement ephiphyte des rhizomes de Posidonies (Posidonia oceanica Drlile). Recl. Trav. Stn. Mar. Endoume, 43 (59): 45-64.

- - \& A. Meintsz, 1982: Découverte de Therbier de Posidonie. Parc National Port-Cros, Parc Naturel Regional de la Corse \& G. I. S. Posidonie Eds.. 4: 1-80.

Bourcier, M. \& A. Wilısıe. 1986: Considérations écologiques sur les Sipunculiens de la matte de Posidonia oceanica (L.) Drille. Rapp. Comm. int. Mer Médit., 30 (2): 8.

Carbonfi.l. J., 1984: Crustacis de les illes Medes. In: J. Ros, I. Olivella \& J. M. Git. (Eds.), Les sistemes naturals de les illes Medes. Inst. d'estud. catalans: 505-530.

Colinvaux. P. A., 1973: Introduction to ecology. John Wiley \& Sons, Inc., New York; 621 pp.

Chissa, L. A., E. Fresi \& L. Sogicu, 1983: Preliminary data on consumers food wed in a Posidonia oceanica (L.) Deill.e bed. Rapp. Comm. int. Mer Médit., 28 (3): 159-160.

- -. M. Scardi, E. Fresi \& P. Russu, 1985: Consumers in Posidonia oceanica beds. 1. Processa edulis (Riso) (Decapoda. Caridea). Second International Workshop in Posidonia oceanica beds. Ischia. Summary.

De Metrio, G., R. Vaccarella, G. Bello \& E. Terio, 1978: Stima dell'area minima nelle "mates" di Posidonia oceanica Delilf (Zoobenthos). Atti. Soc. Pclorit. Sc. Fis. Mat. e Nat., 24 (2): $249-263$.

Ergen, Z., A. Kocatas, T. Katagan \& M. Onen, 1988: The distribution of Polychaeta and Crustacea fauna found in Posidonia oceanica meadows of Aegean Coast of Turkey. Rapp. Comm. int. Mer Médit.. 31 (2): 25. 
García-Raso, J.E.. 1987: Consideraciones taxonómicas sobre algunas especies de Crustáceos Decápodos de fondos de concrecionamiento calcáreo y Posidonia oceanica: Pisidia longicornisPisidia longimana y Galathea bolivari-Galathea cenarroi. Inv. Pesq., 51 (2): 277-292.

- -, 1988: Consideraciones generales sobre la taxocenosis de fondos de concrecionamiento calcáreo superficial del alga Mesophyllum lichenoides (Elbs \& Sol.) Lemoine (Corallinaceae) del mar de Alborán. Inv. Pesq., 52 (2): 245-264.

- - \& R. Fernandez Muñoz, 1987: Estudio de una comunidad de Crustáccos Decápodos de fondos "coralígenos" del alga Mesophyllum lichenoides del sur de España. Inv. Pesq., 51 (supl. 1): 301-322,

Harmelin, J.G., 1964: Etude de l'endofaune des "mattes" d'hcrbiers de Posidonia oceanica Delile. Recl. Trav. Stn. Mar. Endoume, 35 (51): 43-105.

- -, 1973: Bryozoaires de l'herbier de Posidonies de l'île de Port-Cros. Rapp. Réun. Comm. Int. Expl. Mer Medit., 21 (9): 675-677.

Kıкuchı, T., 1980: Faunal relationships in temperate seagrass beds. In: R. C. PHiLlips \& C. P. McRoY (Eds.), Handbook of scagrass biology: An ecosystem perspective. Garland STPM Press, New York: 153-172.

- - \& J. M. Pérès, 1977: Consumer ecology of seagrass beds. In: C. P. McRoy \& C. HelfFerich (Eds.). Scagrass ecosystems. Marcel Dekker Inc., New York: 147-193.

Ledoyer, M., 1966: Ecologie de la faune vagile des biotopes méditerranéens accessibles en scaphandre autonome. II. Données analytiques sur les herbiers de phanérogames. Recl. Trav. Stn. Mar. Endoume, 41 (57): 135-164.

- -, 1968: Ecologic de la faune vagile des biotopes méditerranéens accessibles en scaphandre autonome. IV. Synthèses de l'étude écologique. Recl. Trav. Stn. Mar. Endoume, 44 (60): $125-295$.

Lopez-Ibor, A., C. Galan \& J. Templado, 1982: Echinodermes du Cabo de Palos (Murcia, Espagne). Biol. Ecol. médit., 9 (2): 3-18.

LORENTI, M. \& E. Fresi, 1983: Vertical zonation of vagile fauna from the foliar stratum of a Posidonia oceanica bed. Isopoda. Rapp. Comm. int. Mer Médit., 28 (3): 143-145.

MacArthur, R. H., 1957: On the relative abundance of bird species. Proc. Nat. Acad. Sci.. 43: 293-295.

Margaler, R., 1974: Ecología. Ed. Omega. Barcelona; 951 pp.

Mateu, M., G., 1970: Contribución al conocimiento de los foraminífcros actuales. Estudio sistemático y bioecológico de los foraminíferos vivientes de los litorales de Cataluña y Baleares. Trab. I. E. O., 38: 1-84

Molinier, R., 1959-1960: Etude des biocénoses marines de Cap Corse. Vegetatio, 9: 121-192: $217-312$.

Nedelec, H., M. Verlaque \& A. Dlapoul.ıs, 1981: Preliminary data on Posidonia consumption by Paracentrotus lividus in Corsica (France). Rapp. Comm. int. Mer Médit., 27 (2): 203-204.

Pansini, M. \& R. Pronzato, 1985: Distribution and ecology of epiphytic Porifera in two Posidonia oceanica (L.) Delle meadows of the Ligurian and Tyrrhenian Sea. P.S.Z. N. I: Marine Ecology, $6(1): 1-11$.

Pereira. F.. 1981: Sobre los prosobranquios (Mollusca, Gasteropoda) de Posidonia oceanica. Rapp Comm. int. Mer Médit., 27 (2): 199-200.

Pérès, J. M. \& J. Picard, 1964: Nouveau manuel du bionomie benthique de la méditerranée. Recl. Trav. Stn. Mar. Endoume, 31 (47): 1-137.

Pronzato, R. \& S. Bellon, 1981: Insediamenti zoobentonici su rizomi di Posidonia a diverse profondità. Boll. Mus. Ist. Biol. Univ. Genova, (1980-1981), 48-49: 47-54.

Romero. J., 1985: Estudio ccológico de las fanerógamas marinas de la costa catalana: producción primaria de Posidonia oceanica (L.) Det.t.e en las Islas Medas. Tesis Doctoral, Univ. Barcelona; 261 pp.

Russo. G. F.. E. Fresi \& D. VINCI. 1983: Distribution and diel variations of Mollusk syntaxon in a Posidonia oceanica (L.) Dellle meadow. Rapp. Comm. int. Mer Médit., 28, 3: 139-140.

- -, E. Fresi, D. Vinci \& L. A. Chessa, 1984: Malacofauna di strato foliare delle praterie di Posidonia oceanica (L.) DellLe intorno all' Isola d'Ischia (Golfo di Napoli): Analisi strutturale del popolamento estivo in rapporto alla profondità ed alla esposizione. Nova Thalassia, 1983-84, 6 (Suppl.): 655-661.

San Martin. G. \& J. M. Vieitkz. 1984: Anelidos Poliquetos de los rizomas de Posidonia oceanica en las costas del Cabo de palos (Murcia, España). In: C. F. Boudouresque, J. de Grissac \& 
J. Ol.rvier, (Eds.), International workshop on Posidonia oceanica beds. G. I. S. Posidonic Publ., Fr., 1: 149-157.

Scipione, M. B., E. Fresi \& K. J. Witimann, 1983: The vagile fauna of Posidonia oceanica (L.) Delıle foliar stratum: a community approach. Rapp. Comm. int. Mer Médit., 28 (3): 141-142.

SpadA. G.. 1971: Contributo alla conoscenza della malacofauna della biocenosi a Posidonia oceanica lungo le cote italiane. Conchiglie, 7 (9-10): 125-135.

Templado, J., 1982: Moluscos de las formaciones de Fancrógamas marinas en las costas del Cabo de Palos (Murcia). Tesis Doctoral, Univ, Complutense de Madrid; $332 \mathrm{pp}$.

- - 1984 a: Moluscos de las praderas de Posidonia oceanica en las costas del Cabo de Palos (Murcia, España). Inv. Pesq. , 48 (3): 509-526.

- -, 1984 b: Las praderas de Posidonia oceanica en el sureste español y su biocenosis. In: C. F. Boudouresque, A.J. DE Grissac \& J. Olivile (Eds.), International workshop on Posidonia oceanica beds. G. I. S. Posidonic Publ., Fr., 1: 159-172.

Thayer. G.H., W.J. Kenworthy \& M. Fonseca, 1984: The ecology of eelgrass meadows of Atlantic coast: a community profile. U.S. Fish and Wildlife Serv.: 1-147.

Traer, K., 1980: The consumption of Posidonia oceanica Dellle by Echinoids at the Isle of Ischia. In: M. Jangoux (Ed.), Echinoderms: present and past. A. BalkemA. Rotterdam: 241-244.

Verlaque, M., 1981: Preliminary data on some Posidonia feeders. Rapp. Comm. int. Mer Médit., $27(2): 201-202$.

WILlsie, A., 1983: Zonation de la macrofaune endogée de la matte d’herbier de Posidonia oceanica (L.) Delile. Rapp. Comm. int. Mor Médit., 28 (3): 165-168.

WitTMann, K., M. B. Sciplone \& E. Fresi, 1981: Some laboratory experiments on the activity of the macrofauna in the fragmentation of detrital leaves of Posidonia oceanica (L.) DeLne. Rapp. Comm. int. Mer Médit., 27 (2): 205-206.

Zupi, V. \& E. Fresi, 1985: A study on the food web of Posidonia oceanica (L.) Delile ecosystem: analysis of the gut of Decapod Crustaccans. Rapp. Comm. int. Mer Médit., 29 (5): 189-192.

- - G. F. Russo, E. Fresi \& M.Scardi, 1985: Hermit crabs of a Posidonia bed: zonal patterns and shell selection. Second International Workshop on Posidonia oceanica beds, Ischia. Summary. 